\title{
Kelangsungan Hidup Bayi di Perkotaan dan Pedesaan Indonesia
}

\author{
Demsa Simbolon*
}

\begin{abstract}
Abstrak
Kelangsungan hidup bayi di Indonesia yang masih rendah terlihat pada angka kematian bayi (AKB) yang menempati posisi tertinggi di Asean, kondisi intermediate rock dan sangat bervariasi. Penelitian yang menggunakan sumber data sekunder SDKI 2002-2003 ini bertujuan mengetahui gambaran kelangsungan hidup bayi di wilayah perkotaan dan pedesaan di Indonesia serta berbagai faktor yang berpengaruh. Besar sampel yang digunakan adalah 11.588 terdiri dari 4.769 bayi di perkotaan dan 6.819 bayi di pedesaan. Metoda analisis yang digunakan meliputi metode life table dan regresi cox. Hasil penelitian memperlihatkan probabilitas kelangsungan hidup bayi di perkotaan $(98,59 \%)$ lebih tinggi daripada bayi di pedesaan $(97,54 \%)$ dan proporsi kematian bayi di pedesaan dua kali lebih besar daripada di perkotaan. Pada masa neonatal, kurva kelangsungan hidup bayi memperlihatkan kecenderungan yang menurun tajam dan post neonatal terlihat lebih landai. Penurunan probabilitas kelangsungan hidup bayi di wilayah perkotaan terlihat lebih landai daripada di wilayah pedesaan. Terdapat perbedaan faktor-faktor yang berhubungan dengan kelangsungan hidup bayi di perkotaan dan pedesaan. Di perkotaan, faktor-faktor yang berhubungan dengan kelangsungan hidup bayi meliputi berat badan lahir, waktu pemberian ASI dan penolong persalinan. Sedangkan di pedesaan, faktor tersebut adalah frekuensi pemeriksaan antenatal, berat badan lahir, penolong persalinan, nomor urut lahir, waktu pemberian ASI dan tempat persalinan. Keadaan saat lahir merupakan faktor penting yang berhubungan signifikan dengan kelangsungan hidup bayi, faktor waktu pemberian ASI pertama kali merupakan faktor dominan yang berhubungan dengan kelangsungan hidup bayi.
\end{abstract}

Kata kunci : Kelangsungan hidup bayi, perkotaan dan pedesaan, analisis kesintasan.

\begin{abstract}
Infant's survival in Indonesia is still low, as showed by the highest IMR level in ASEAN, intermediate rock condition and highly varied. This research's aim is to describe infant's survival in Indonesia's urban and rural area, also various factors related. This research is using SDKI 2002-2003 data. Sample's amount 11.588 infant, consist of 4.769 infant in urban and 6.819 infant in rural. Method of analysis used in this study is life table and cox regression. This research found probability infant's survival in urban $(98,59 \%)$ higher than in rural $(97,54 \%)$ and infant's mortality proportion in rural is twice higher than in urban. On first month age (neonatal mortality) infant's survival time probability was decline, and for higher age infant's survival time probability is still low, but not as low as the first month age. In urban area, infant's survival time probability is even lower than in rural. There are determinant factors which are related to infant's survival in rural and urban. In urban, factors which are related to infant's survival are birth weight, breast feeding period and birth assistance. Meanwhile in rural area, the factors of are antenatal care, birth weight, birth assistance, birth queue number, breast feeding period and bearing place. Infant condition when the baby born is determinant factors which is related significantly with infant's survival, first breast feeding period is dominant factor which is related with infant's survival.
\end{abstract}

Key words : Infant survival, rural and urban, survival analysis.

*Staf Pengajar Politeknik Kesehatan Bengkulu. 
Ancaman terhadap kelangsungan hidup bayi tercermin pada Angka Kematian Bayi (AKB) yang tinggi. Di Indonesia, program pembangunan yang dilaksanakan tampaknya berpengaruh terhadap penurunan AKB. Namun, penurunan yang terjadi setelah tahun 70-an terlihat berjalan lambat dan cenderung bertahan. AKB di Indonesia masih tetap berada pada keadaan intermediate rock, dan sangat bervariasi antar wilayah, yaitu 32 per 1.000 kelahiran hidup (KH) di perkotaan dan 52 per $1.000 \mathrm{KH}$ di pedesaan. Pada tahun 2002, AKB Indonesia masih di urutan tertinggi keenam setelah Singapura ( 3 per $1.000 \mathrm{KH}$ ), Brunai Darussalam (6 per $1.000 \mathrm{KH})$, Malaysia $(8$ per $1.000 \mathrm{KH})$, Filipina (29 per $1.000 \mathrm{KH})$, Thailand (24 per $1.000 \mathrm{KH})$, Vietnam (30 per $1.000 \mathrm{KH}$ ). AKB yang lebih rendah dari Indonesia (35 per $1.000 \mathrm{KH}$ ) adalah Myanmar (77 per $1.000 \mathrm{KH}$ ), Laos (87 per $1.000 \mathrm{KH}$ ) dan Kamboja (96 per $1.000 \mathrm{KH}) .{ }^{1}$ Kematian bayi dan anak dipengaruhi oleh faktor sosial ekonomi pada tingkat individu, keluarga, dan masyarakat. Variabel antara yang mempengaruhi kematian bayi meliputi faktor maternal, kesehatan perorangan, lingkungan, gizi, luka dan pengendalian kesehatan perorangan. ${ }^{2}$ Kelangsungan hidup bayi sangat ditentukan oleh kondisi pertumbuhan janin di dalam uterus, kualitas pemeriksaan antenatal, penyakit ibu waktu hamil, penanganan persalinan dan perawatan sesudah lahir. Setiap bayi lahir dihadapkan pada kondisi yang berbeda, sehingga diperkirakan mempunyai umur kelangsungan hidup yang berbeda pula. ${ }^{3}$ Untuk mengetahui probabilitas kelangsungan hidup bayi pada setiap kelompok umur bayi hanya dapat diketahui dengan melakukan analisis kesintasan.

\section{Metode}

Penelitian dengan desain penelitian cross sectional ini dilakukan dengan metoda analisis kesintasan (Survival) terhadap sumber data sekunder SDKI tahun 2002-2003. Data yang menyediakan informasi tentang waktu dan kejadian itu, memberi peluang untuk melakukan analisis kelangsungan hidup bayi di perkotaan dan pedesaan Indonesia berikut faktor-faktor yang berhubungan. Populasi yang diamati pada studi adalah bayi yang lahir hidup pada periode 1997-2002. Unit analisis adalah bayi anak terakhir yang lahir hidup pada periode 1997-2002 dan pada saat wawancara berumur minimal 1 tahun. Waktu kelangsungan hidup bayi diukur terhadap lama bayi bertahan hidup sejak lahir sampai pengamatan 1 tahun. Kasus yang diamati pada penelitian ini adalah kematian, sensor terjadi jika setelah pengamatan berakhir tidak terjadi kasus. Besar sampel yang memenuhi kriteria penelitian adalah 11.588 bayi yang terdiri dari 4.769 bayi yang tinggal di perkotaan dan 6.819 bayi di pedesaan. Kriteria eksklusi pada penelitian ini adalah ibu yang tidak mengetahui tanggal kelahiran anaknya.

\section{Hasil}

Berdasarkan pengamatan terhadap 11.588 bayi yang lahir hidup, ditemukan angka kematian bayi adalah 2,03\%, yaitu $1,41 \%$ di perkotaan dan $2,46 \%$ di pedesaan. Proporsi kematian bayi di daerah pedesaan ditemukan 1,74 kali lebih besar daripada bayi didaerah perkotaan. Secara keseluruhan, probabilitas kumulatif kelangsungan hidup bayi yang mencapai umur 1 tahun atau lebih adalah 97,97\%. Probabilitas kumulatif kelangsungan hidup bayi di perkotaan lebih tinggi daripada di pedesaan. Probabilitas kelangsungan hidup bayi pada bulan pertama terlihat menurun cukup tajam. Pada umur selanjutnya, probabilitas kelangsungan hidup bayi terlihat menurun, tetapi tidak setajam seperti pada umur bulan pertama (Lihat Gambar 1). Penurunan probabilitas kelangsungan hidup bayi di perkotaan terlihat lebih landai daripada di pedesaan (Lihat Gambar 2).

\section{Karakteristik Ibu}

Secara keseluruhan terlihat bahwa distribusi bayi

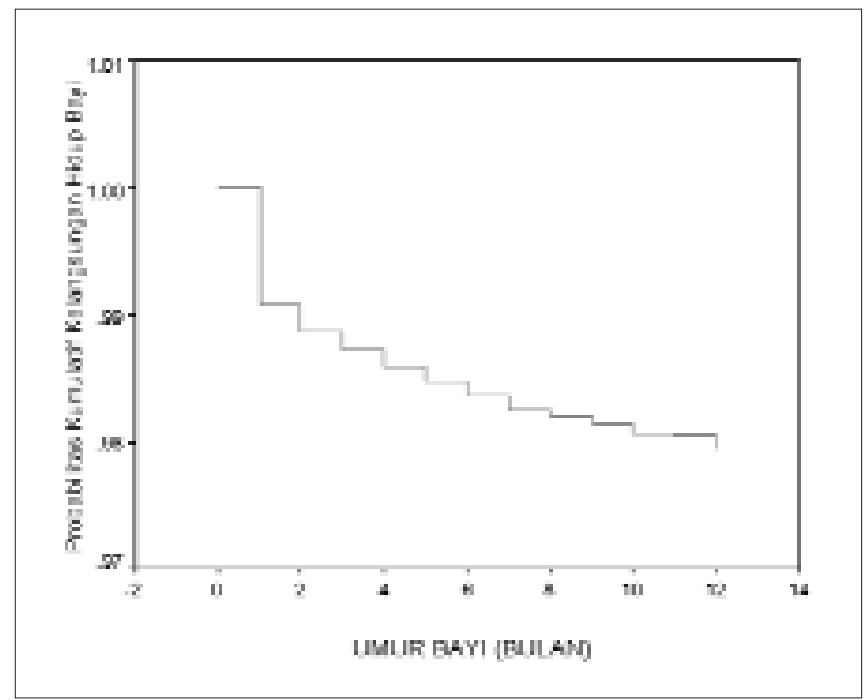

Gambar 1. Kurva Kelangsungan Hidup Bayi di Indonesia

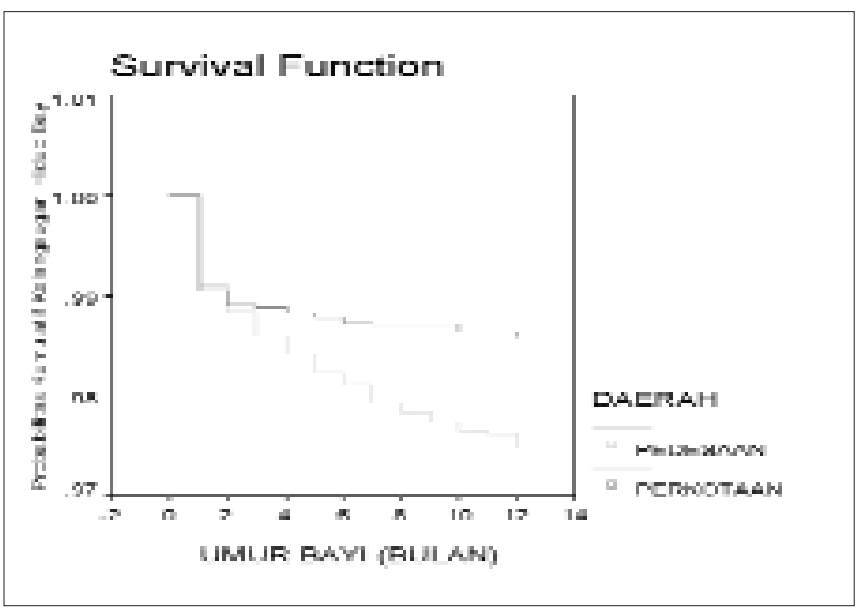

Gambar 2. Kurva Kelangsungan Hidup Bayi Menurut Wilayah Perkotaan dan Pedesaan di Indonesia 
berdasarkan status pekerjaan ibu hampir merata. Ibu berpendidikan tinggi (63\%), berumur $20-35$ tahun (78\%). Ibu yang tidak pernah mengalami komplikasi persalinan $(64 \%)$, dan tinggal di lingkungan yang baik $(75 \%)$. Di perkotaan, proporsi keadaan lingkungan hampir sama. Lebih dari setengah ibu berpendidikan tinggi (63\%), tidak bekerja $(61 \%)$, sebagian besar berumur 20-35 tahun $(80 \%)$, tidak mengalami komplikasi kehamilan $(92 \%)$, dan tidak mengalami komplikasi persalinan (62\%). Di pedesaan, proporsi ibu menurut status pekerjaan hampir sama, lebih dari setengah ibu berpendidikan rendah (60\%), berumur 20-35 tahun (76\%), tidak mengalami komplikasi kehamilan (94\%), tidak mengalami komplikasi persalinan $(66 \%)$, dan keadaan lingkungan buruk $(89 \%)$.

Berdasarkan faktor pelayanan antenatal terlihat bahwa lebih dari setengah frekuensi pelayanan antenatal sesuai dengan standar minimal (61\%), tetapi sebagian besar mendapat komponen pemeriksaan yang kurang lengkap (94\%), Pemeriksaan antenatal sebagian besar dilakukan oleh tenaga kesehatan $(90 \%)$. Frekuensi kunjungan pemeriksaan antenatal di perkotaan dan pedesaan sebagian besar telah sesuai standar, tetapi proporsi ibu yang tidak melakukan pemeriksaan antenatal lebih tinggi di pedesaan. Ibu yang mendapat komponen pemeriksaan kehamilan yang lengkap sangat sedikit.

Berdasarkan keadaan saat persalinan, sebagian besar ibu $(68 \%)$ bersalin ditolong oleh tenaga kesehatan dan bukan di fasilitas kesehatan (62\%). Di pedesaan, proporsi jenis tenaga penolong persalinan hampir sama, sedangkan di perkotaan sebagian besar persalinan ditolong oleh tenaga kesehatan $(85 \%)$ dan di fasilitas kesehatan $(62 \%)$, sedangkan di pedesaan sebagian besar bukan di fasilitas kesehatan $(73 \%)$. Berdasarkan jenis kelamin bayi, proporsi bayi lakilaki dan bayi perempuan serta di perkotaan dan pedesaan hampir sama besar. Sebagian besar bayi lahir dengan berat badan lahir normal, jarak kelahiran 2 tahun atau lebih, nomor urut lahir anak ke-2 sampai anak ke-4 dan mendapat ASI 1 jam setelah persalinan.

\section{Analisis Life Table}

Analisis life table memperlihatkan bahwa probabilitas kumulatif kelangsungan hidup lebih tinggi pada bayi yang lahir dari ibu yang berpendidikan tinggi, tidak bekerja, umur ibu 20-35 tahun, tidak ada komplikasi kehamilan dan lingkungan baik (Lihat Tabel 1). Sedangkan berdasarkan komplikasi persalinan ditemukan kecenderungan yang berbeda. Bayi yang lahir dari ibu yang pernah mengalami komplikasi persalinan justru memperlihatkan probabilitas kumulatif yang lebih tinggi (Lihat Tabel 2). Hal yang sama ditemukan pada bayi yang lahir dari ibu dengan frekuensi antenatal sesuai standar, komponen pemeriksaan kehamilan lengkap, pemeriksa kehamilan dan penolong persalinan tenaga kesehatan, tempat persalinan di fasilitas kesehatan, bayi perempuan, bayi berat badan lahir normal, jarak ke-
Tabel 1. Probabilitas Kumulatif Kelangsungan Hidup Bayi Menurut Faktor Ibu

\begin{tabular}{lc}
\hline Variabel & Kota + Desa \\
\hline Pendidikan Ibu & \\
Tinggi & $98,38 \%$ \\
Rendah & $97,67 \%$ \\
Tidak Pernah Sekolah & $97,28 \%$ \\
Pekerjaan Ibu & \\
Tidak bekerja & $98,17 \%$ \\
Bekerja & $97,75 \%$ \\
Umur Saat Melahirkan & \\
$<20$ tahun & $98,18 \%$ \\
20-35 tahun & $98,02 \%$ \\
$>35$ tahun & $97,50 \%$ \\
Komplikasi Kehamilan & \\
Tidak ada & $97,99 \%$ \\
Ada & $97,72 \%$ \\
Komplikasi Persalinan & \\
Tidak ada & $97,92 \%$ \\
Ada & $98,06 \%$ \\
Lingkungan & \\
Baik & $98,58 \%$ \\
Buruk & $97,77 \%$ \\
\hline
\end{tabular}

Tabel 2. Probabilitas Kumulatif Kelangsungan Hidup Bayi Menurut Faktor Pelayanan Antenatal

\begin{tabular}{lc}
\hline Variabel & Kota + Desa \\
\hline Frekuensi ANC & \\
Sesuai standar & $98,70 \%$ \\
Tidak sesuai standar & $96,96 \%$ \\
Tidak ANC & $95,58 \%$ \\
Komponen ANC & \\
Lengkap & $99,05 \%$ \\
Kurang lengkap & $98,01 \%$ \\
Tidak lengkap & $95,94 \%$ \\
Petugas ANC & \\
Nakes & $98,17 \%$ \\
Non Nakes & $96,19 \%$ \\
\hline
\end{tabular}

Tabel 3. Probabilitas Kumulatif Kelangsungan Hidup Bayi menurut Faktor Keadaan Saat Bayi Lahir

\begin{tabular}{lc}
\hline Variabel & Kota + Desa \\
\hline Penolong Persalinan & \\
Nakes & $98,60 \%$ \\
Non Nakes & $96,65 \%$ \\
Tempat Persalinan & \\
Fas. Kesehatan & $98,96 \%$ \\
Non Kesehatan & $97,99 \%$ \\
Jenis Kelamin & \\
Perempuan & $98,20 \%$ \\
Laki-laki & $97,76 \%$ \\
Berat Badan Lahir & \\
BBLN & $98,82 \%$ \\
BBLR & $95,93 \%$ \\
Tidak Ditimbang & $95,86 \%$ \\
Jarak Kelahiran & \\
$<2$ tahun & $98,19 \%$ \\
$\geq 2$ tahun & $96,84 \%$ \\
Nomor Urut Anak & \\
2 - 4 Anak & $98,18 \%$ \\
1 Anak & $98,33 \%$ \\
$\geq 5$ Anak & $96,13 \%$ \\
Waktu Pemberian Asi & \\
< 1 jam & $98,29 \%$ \\
Tidak dapat ASI & $98,62 \%$ \\
\hline
\end{tabular}


lahiran 2 tahun atau lebih, nomor urut lahir anak ke-2 sampai anak ke-4, dan waktu pemberian ASI kurang dari 1 jam setelah lahir (Lihat Tabel 3).

Penelitian ini juga menemukan bahwa faktor-faktor yang berhubungan dengan kelangsungan hidup bayi di Indonesia adalah frekuensi pemeriksaan antenatal, berat badan lahir, jarak kelahiran, nomor urut lahir, waktu pemberian ASI, penolong persalinan, interaksi penolong persalinan dengan berat badan lahir, interaksi penolong persalinan dengan waktu pemberian ASI pertama kali, dengan variabel pengontrol utama adalah daerah tempat tinggal (Lihat Tabel 4).

Faktor dominan yang berhubungan dengan kelangsungan hidup bayi adalah waktu pemberian ASI pertama kali. Pada analisis multivariat, bayi yang lahir dari ibu dengan frekuensi antenatal yang tidak standar besisiko mati 1,43 kali lebih besar daripada bayi yang lahir dari ibu dengan frekuensi antenatal yang standar. Bayi yang lahir dengan jarak kurang dari 2 tahun berisiko mati 1,41 kali lebih besar daripada bayi yang jarak kelahirannya lebih dari 2 tahun. Bayi anak ke-5 atau lebih berisiko mati 1,65 kali lebih besar daripada bayi anak ke-2 sampai ke-4. Interaksi antara variabel berat badan lahir dengan penolong persalinan, menunjukkan bahwa efek berat badan lahir bayi tergantung pada penolong persalinan dan waktu survival. Pada persalinan tenaga kesehatan, risiko kematian bayi BBLR dan bayi yang tidak ditimbang berisiko kematian 5,68 dan 4,72 kali lebih besar daripada bayi berat lahir normal. Pada per- salinan bukan tenaga kesehatan, bayi BBLR dan bayi yang tidak ditimbang berisiko 1,54 dan 4,72 kali lebih besar daripada bayi berat lahir normal. Selanjutnya, berdasarkan variabel interaksi, terlihat bahwa efek pemberian ASI tergantung pada penolong persalinan. Pada persalinan yang ditolong oleh bukan tenaga kesehatan, risiko kematian pada bayi yang tidak mendapat ASI 26,19 kali lebih besar daripada bayi yang segera mendapat ASI. Pada bayi persalinan bukan tenaga, risiko kematian pada bayi yang tidak mendapat ASI adalah 2,25 kali lebih besar daripada bayi yang segera mendapat ASI. Nilai hazard kematian yang bersifat protektif, menunjukkan peranan penting penolong persalinan mendorong ibu untuk segera memberikan ASI kepada bayinya.

Faktor-faktor yang berhubungan dengan kelangsungan hidup bayi di perkotaan dapat dilihat pada model akhir tabel 5. Terlihat bahwa bahwa faktor-faktor yang berhubungan dengan kelangsungan hidup bayi di perkotaan meliputi berat badan lahir, waktu pemberian ASI pertama kali, penolong persalinan dan interaksi penolong persalinan dengan berat badan lahir setelah dikontrol faktor frekuensi antenatal, tempat persalinan dan nomor urut lahir.

Faktor dominan yang berhubungan dengan kelangsungan hidup bayi adalah pemberian ASI pertama kali. Waktu pemberian ASI berhubungan dengan kelangsungan hidup, bayi yang tidak mendapat ASI berisiko mengalami kematian bayi 22,68 kali lebih besar daripada yang segera setelah kelahiran $(<1$ jam $)$ mendapat ASI, setelah variabel

Tabel 4. Model Akhir Kelangsungan Hidup Bayi di Indonesia

\begin{tabular}{|c|c|c|c|c|c|}
\hline Variabel & Kategori & - & $\mathbf{p}$ & HR & $95 \% \mathrm{CI}$ \\
\hline Daerah & * Pedesaan & 0,193 & 0,242 & 1,213 & $0,878-1,674$ \\
\hline \multirow[t]{2}{*}{ Frekuensi ANC } & * Tidak sesuai & 0,357 & 0,016 & 1,429 & $1,069-1,909$ \\
\hline & *Tidak ANC & 0,460 & 0,059 & 1,584 & $0,983-2,552$ \\
\hline Tempat Persalinan & * Non-Kesehatan & 0,335 & 0,080 & 1,398 & $0,960-2,034$ \\
\hline \multirow[t]{2}{*}{ Berat Badan Lahir } & * BBLR & 1,738 & 0,000 & 5,684 & $2,974-10,864$ \\
\hline & * Tidak Ditimbang & 1,552 & 0,000 & 4,722 & $2,771-8,048$ \\
\hline Jarak Kelahiran & $*<2$ tahun & 0,346 & 0,032 & 1,414 & $1,029-1,942$ \\
\hline \multirow[t]{2}{*}{ Nomor Urut Lahir } & * Anak pertama & 0,069 & 0,678 & 1,072 & $0,772-1,488$ \\
\hline & $* \geq$ Anak ke-5 & 0,501 & 0,002 & 1,650 & $1,194-2,280$ \\
\hline \multirow[t]{2}{*}{ Waktu Pemberian ASI } & $* \geq 1$ jam & 0,356 & 0,218 & 1,427 & $0,810-2,516$ \\
\hline & * Tidak mendapat ASI & 3,265 & 0,000 & 26,192 & $14,696-46,682$ \\
\hline Penolong Persalinan & *Non-Kesehatan & 1,592 & 0,000 & 4,913 & $2,535-9,524$ \\
\hline \multirow[t]{2}{*}{ BBL*Penolong Persalinan } & *BBL(1)*Penolong & $-1,307$ & 0,000 & 0,271 & $0,084-0,863$ \\
\hline & * BBL $(2) *$ Penolong & $-1,283$ & 0,021 & 0,277 & $0,150-0,511$ \\
\hline \multirow[t]{2}{*}{ ASI*Penolong Persalinan } & $* \operatorname{ASI}(1) *$ Penolong & $-0,833$ & 0,017 & 0,435 & $0,219-0,863$ \\
\hline & *ASI $(2) *$ Penolong & $-1,017$ & 0,010 & 0,362 & $0,167-0,782$ \\
\hline \multirow[t]{2}{*}{$\mathrm{T}_{-} \mathrm{COV}_{-} * \mathrm{BBL}$} & ${ }^{*} \mathrm{~T}_{-} \mathrm{COV}_{-}{ }^{*} \mathrm{BBL}(1)$ & $-0,301$ & 0,027 & 0,740 & $0,566-0,966$ \\
\hline & ${ }^{*} \mathrm{~T}_{-} \mathrm{COV}_{-}{ }^{*} \mathrm{BBL}(2)$ & $-0,027$ & 0,541 & 0,973 & $0,893-1,061$ \\
\hline
\end{tabular}


Tabel 5. Model Akhir Kelangsungan Hidup Bayi di Perkotaan

\begin{tabular}{|c|c|c|c|c|c|}
\hline Variabel & Kategori & - & $\mathbf{p}$ & HR & $95 \% \mathrm{CI}$ \\
\hline Berat Badan Lahir & $\begin{array}{l}* \text { BBLR } \\
* \text { Tidak Ditimbang }\end{array}$ & $\begin{array}{l}1,470 \\
2,709\end{array}$ & $\begin{array}{l}0,000 \\
0,000\end{array}$ & $\begin{array}{l}4,349 \\
15,016\end{array}$ & $\begin{array}{r}2,008-9,419 \\
6,372-35,390\end{array}$ \\
\hline Waktu Pemberian ASI & $\begin{array}{l}* \geq 1 \text { jam } \\
* \text { Tidak mendapat ASI }\end{array}$ & $\begin{array}{l}0,064 \\
3,121\end{array}$ & $\begin{array}{l}0,863 \\
0,000\end{array}$ & $\begin{array}{l}1,066 \\
22,679\end{array}$ & $\begin{array}{r}0,516-2,203 \\
11,188-45,973\end{array}$ \\
\hline Penolong Persalinan & $\begin{array}{l}\text { * Tenaga Kesehatan } \\
\text { * Non-Kesehatan }\end{array}$ & 1,625 & 0,002 & 5,078 & $1,820-14,170$ \\
\hline Penolong persalinan*BBL & $\begin{array}{l}* \text { BBL }(1) * \text { Penolong } \\
* \operatorname{BBL}(2) * \text { Penolong }\end{array}$ & $\begin{array}{l}-1,011 \\
-1,970\end{array}$ & $\begin{array}{l}0,252 \\
0,002\end{array}$ & $\begin{array}{l}0,364 \\
0,140\end{array}$ & $\begin{array}{l}0,064-2,056 \\
0,041-0,474\end{array}$ \\
\hline Frekuensi ANC & $\begin{array}{l}\text { * Tidak sesuai } \\
* \text { Tidak ANC }\end{array}$ & $\begin{array}{l}0,213 \\
0,807\end{array}$ & $\begin{array}{l}0,440 \\
0,107\end{array}$ & $\begin{array}{l}1,238 \\
2,241\end{array}$ & $\begin{array}{l}0,720-2,128 \\
0,840-5,981\end{array}$ \\
\hline Tempat Persalinan & $\begin{array}{l}\text { * Fasilitas Kesehatan } \\
* \text { Non-Kesehatan }\end{array}$ & $-0,310$ & 0,415 & 0,733 & $0,348-1,546$ \\
\hline Nomor Urut Lahir & $\begin{array}{l}* \text { Anak pertama } \\
* \geq \text { Anak ke-5 }\end{array}$ & $\begin{array}{l}0,027 \\
0,458\end{array}$ & $\begin{array}{l}0,925 \\
0,167\end{array}$ & $\begin{array}{l}1,028 \\
1,581\end{array}$ & $\begin{array}{l}0,583-1,812 \\
0,825-3,027\end{array}$ \\
\hline
\end{tabular}

Tabel 6. Model Akhir Kelangsungan Hidup Bayi di Pedesaan

\begin{tabular}{|c|c|c|c|c|c|}
\hline Variabel & Kategori & - & $\mathbf{p}$ & HR & $\mathbf{9 5} \% \mathrm{CI}$ \\
\hline \multirow[t]{2}{*}{ Frekuensi ANC } & Tidak sesuai & 0,394 & 0,026 & 1,482 & $1,049-2,095$ \\
\hline & Tidak ANC & 0,380 & 0,169 & 1,496 & $0,851-2,516$ \\
\hline \multirow[t]{2}{*}{ Berat Badan Lahir } & BBLR & 0,467 & 0,128 & 1,595 & $0,866-3,138$ \\
\hline & Tidak Ditimbang & 0,409 & 0,029 & 1,506 & $1,045-2,306$ \\
\hline Penolong Persalinan & Non-Kesehatan & 0,986 & 0,009 & 2,565 & $1,266-5,198$ \\
\hline \multirow[t]{2}{*}{ Nomor Urut Lahir } & Anak pertama & $-0,059$ & 0,866 & 1,034 & $0,698-1,532$ \\
\hline & $\geq$ Anak ke-5 & 0,445 & 0,021 & 1,556 & $1,069-2,266$ \\
\hline \multirow[t]{2}{*}{ Waktu Pemberian ASI } & $\geq 1$ jam & 0,242 & 0,321 & 1,413 & $0,714-2,798$ \\
\hline & Tidak dapat ASI & 4,829 & 0,000 & 27,983 & $13,489-58,054$ \\
\hline Tempat Persalinan & Non-Kesehatan & 0,530 & 0,040 & 1,699 & $1,024-2,818$ \\
\hline \multirow[t]{2}{*}{ Penolong Persalin*ASI } & ASI(1)*Penolong & $-0,801$ & 0,049 & 0,449 & $0,202-0,996$ \\
\hline & ASI(2)*Penolong & $-1,530$ & 0,002 & 0,217 & $0,081-0,579$ \\
\hline Jarak Kelahiran & $<2$ tahun & 0,331 & 0,081 & 1,393 & $0,959-2,021$ \\
\hline Jenis Kelamin & Laki-laki & 0,300 & 0,056 & 1,350 & $0,992-1,838$ \\
\hline
\end{tabular}

lain yang ada dalam model dikendalikan. Pada persalinan yang ditolong oleh tenaga kesehatan, risiko kematian bayi BBLR 4,3 kali lebih besar. Bayi yang tidak ditimbang dan bayi yang ditolong bukan tenaga kesehatan berisiko 15,02 kali dan 1,58 kali lebih besar daripada bayi berat lahir normal dan persalinan tenaga kesehatan, setelah dikontrol berbagai variabel perancu.

Faktor-faktor yang berhubungan dengan kelangsungan hidup bayi di pedesaan dapat dilihat pada model akhir tabel 6. Faktor tersebut meliputi frekuensi kunjungan pelayanan antenatal, berat badan lahir, nomor urut lahir, waktu pem- berian ASI, penolong persalinan, tempat persalinan, jarak kelahiran dan jenis kelamin bayi. Faktor penolong persalinan terlihat berinteraksi dengan waktu pemberian ASI.

Setelah dikontrol variabel lain yang ada dalam model, bayi yang lahir dari ibu dengan frekuensi kunjungan antenatal tidak standar berisiko 1,48 kali lebih besar daripada bayi yang lahir dari ibu dengan frekuensi kunjungan pelayanan antenatal sesuai dengan standar. Bayi yang tidak ditimbang berisiko kematian 1,55 kali lebih besar daripada bayi berat badan lahir normal. Namun, tidak ditemukan perbedaan risiko kematian antara bayi BBLR dengan bayi 
berat lahir normal. Bayi anak ke-5 atau lebih berisiko kematian 1,56 kali lebih besar daripada bayi anak ke-2 sampai ke-4. Bayi yang lahir di bukan fasilitas kesehatan berisiko kematian 1,71 kali lebih besar daripada bayi yang lahir di fasilitas kesehatan. Interaksi antara waktu pemberian ASI dengan penolong persalinan memperlihatkan bahwa efek pemberian ASI dipengaruhi oleh penolong persalinan. Pada persalinan bukan tenaga kesehatan, bayi yang tidak mendapat ASI berisiko kematian 26,192 kali lebih besar daripada bayi yang segera mendapat ASI. Pada bayi dengan persalinan bukan tenaga kesehatan, bayi yang tidak mendapat ASI berisiko 2,25 kali lebih besar daripada bayi yang segera mendapat ASI.

\section{Pembahasan}

Meskipun sangat kecil, angka kematian bayi yang hanya terbatas pada wanita yang masih hidup relatif lebih rendah daripada yang sebenarnya. Hal tersebut kemungkinan disebabkan oleh tingkat kematian bayi pada ibu yang telah meninggal lebih tinggi daripada bayi yang lahir dari ibu yang masih hidup. ${ }^{4}$ Di Bangladesh, sekitar $60 \%$ bayi yang mengalami kematian ibu akan meninggal dunia 1 tahun setelah lahir. Probabilitas kelangsungan hidup bayi menurun tajam pada umur 1 bulan yang merupakan masa kritis bagi kelangsungan hidup bayi. Pada umur berikutnya, probabilitas tersebut masih mengalami penurunan, tetapi tidak setajam seperti pada umur 1 bulan. Itu berati bahwa kematian neonatal merupakan penyumbang kematian bayi terbanyak. Hasil analisis SKRT (2001) memperlihatkan bahwa penyebab utama kematian neonatal adalah BBLR (29\%), asfiksia $(27 \%)$ dan tetanus neonatorium $(10 \%) .^{5}$

Penelitian ini menemukan bahwa faktor daerah merupakan faktor pengontrol utama hubungan berbagai faktor lain dengan kelangsungan hidup bayi. Probabilitas kumulatif kelangsungan hidup bayi di perkotaan lebih tinggi daripada di pedesaan. Masyarakat kota pada umumnya berada pada tingkat sosial ekonomi, pendidikan, pendapatan serta penyediaan air dan sanitasi yang lebih baik. Selain itu, pelayanan kesehatan modern dan tenaga kesehatan lebih terkonsentrasi di kota. ${ }^{6}$ Zahid $^{7}$ menyatakan bahwa perbedaan kelangsungan hidup bayi di perkotaan dan pedesaan disebabkan karena perbedaan standar kehidupan, faktor kesehatan lingkungan, persediaan air bersih, dan ketidakseimbangan distribusi fasilitas kesehatan antara perkotaan dan pedesaan pada suatu negara.

Frekuensi pemeriksaan antenatal berhubungan dengan kelangsungan hidup bayi, tetapi model di perkotaan menunjukan bahwa hubungan ini tidak signifikan. Temuan ini bertentangan dengan temuan Asefa, ${ }^{8}$ bayi yang lahir dari ibu yang tidak melakukan antenatal berisiko untuk mati 1,26 kali lebih besar daripada bayi yang lahir dari ibu yang melakukan antenatal. Risiko kematian yang tinggi pada bayi yang lahir dari ibu dengan frekuensi antenatal tidak standar dipengaruhi oleh banyak faktor, yang meliputi: faktor akses terhadap pelayanan (jarak, jumlah, waktu, tipe daerah), faktor sosial ibu hamil (pendidikan, pengetahuan, sikap), faktor keadaan ekonomi keluarga (belanja keluarga/bulan, biaya ke pelayanan dan keterbatasan sarana), faktor reproduksi ibu hamil (umur, paritas), faktor kondisi kesehatan selama hamil (keluhan, kesehatan, hemoglobin), dan faktor pencarian pengobatan (tindakan bila sakit). ${ }^{9}$

Kelengkapan komponen pemeriksaan kehamilan, dan tenaga periksa kehamilan terlihat tidak berhubungan secara bermakna dengan kelangsungan hidup bayi. Padahal, kontak dengan petugas kesehatan seharusnya dapat menurunkan risiko kematian bayi karena dapat mendeteksi secara dini komplikasi kehamilan dan merujuknya pada fasilitas pelayanan yang lebih lengkap. Selain itu, selama periode kehamilan, petugas dapat memberikan pelayanan dasar seperti pemberian tablet $\mathrm{Fe}$, Imunisasi TT serta penyuluhan dan motivasi. Petugas kesehatan juga lebih mampu dalam pencarian pertolongan yang memadai secara tepat waktu. Namun, penelitian ini juga menemukan bahwa banyak ibu yang melakukan pemeriksaan antenatal pada tenaga kesehatan, tapi bersalin pada dukun karena relatif lebih murah, mudah, dan dapat membantu pekerjaan rumah tangga. ${ }^{10}$ Selain itu, adanya persepsi masyarakat bahwa persalinan oleh petugas kesehatan merupakan pertanda tidak sehat. Riwayat persalinan sebelumnya juga diperkirakan berhubungan dengan persalinan berikutnya. ${ }^{11}$ Dari beberapa alasan tersebut, dapat disimpulkan bahwa status sosial ekonomi keluarga yang rendah menyebabkan ibu tidak memanfaatkan tenaga kesehatan sebagai penolong persalinan. Dengan demikian, perlu dilakukan upaya memberdayakan ibu hamil untuk mendapat pertolongan persalinan tenaga kesehatan.

Penolong persalinan merupakan faktor penting yang berhubungan dengan kelangsungan hidup bayi. Proporsi pertolongan persalinan oleh tenaga kesehatan di pedesaan masih sangat jauh di bawah target persalinan tenaga kesehatan Indonesia Sehat 2010 (90\%). ${ }^{12}$ Studi ini menemukan hubungan yang bermakna antara penolong persalinan dengan kelangsungan hidup bayi di perkotaan dan pedesaan. Temuan ini sesuai dengan temuan Harto ${ }^{11}$ dan Maisni, ${ }^{13}$ bahwa bayi yang lahir dengan tenaga non kesehatan berisiko kematian 3,11 dan 2,19 kali lebih besar daripada bayi yang ditolong oleh tenaga kesehatan.

Di Indonesia secara keseluruhan, penolong persalinan merupakan prakondisi pengaruh berat badan lahir dan waktu pemberian ASI pertama kali terhadap kelangsungan hidup bayi. Di perkotaan, faktor penolong persalinan merupakan faktor prakondisi pengaruh berat badan lahir terhadap kelangsungan hidup bayi. Sedangkan di pedesaan merupakan prakondisi untuk pengaruh waktu pemberian ASI pertama kali terhadap kelangsungan hidup bayi. Bayi yang dilahirkan oleh tenaga non kesehatan berisiko kematian tinggi, kemungkinan akibat penggunaan alat-alat yang tidak steril dan berisiko tinggi tetanus neonatorum. 
Penolong persalinan bukan tenaga kesehatan tersebut juga kurang mampu mendeteksi dan mengenal kelainan/komplikasi persalinan secara dini, sehingga terlambat rujukan dan memperbesar risiko kematian keselamatan ibu dan bayi. Penelitian ini juga menemukan bahwa risiko kematian bayi yang dilahirkan oleh tenaga kesehatan masih tergolong tinggi. Hal ini kemungkinan disebabkan oleh rujukan yang terlambat yang memperburuk kondisi ibu hamil.

Hasil penelitian menunjukkan kesenjangan tingkat akses fasilitas pelayanan kesehatan yang sangat besar antara masyarakat perkotaan dan masyarakat pedesaan. Akses pelayanan persalinan di daerah pedesaan yang rendah antara lain disebabkan oleh fasilitas kesehatan yang kurang. Di pedesaan, tempat persalinan merupakan faktor kelangsungan hidup bayi yang penting. Bayi yang tidak lahir di fasilitas kesehatan berisiko mengalami kematian hampir dua kali lebih besar daripada bayi yang lahir di fasilitas kesehatan. Temuan ini sesuai dengan temuan Taffa dan Obare ${ }^{14}$ di Kenya Ethiopia bahwa bayi yang lahir di rumah berisiko untuk mati 1,12 sampai 2,3 kali lebih besar daripada bayi yang lahir di fasilitas kesehatan. Namun, secara keseluruhan di Indonesia tempat persalinan bukan merupakan faktor penentu kelangsungan hidup bayi.

Jenis kelamin terlihat tidak berhubungan secara signifikan dengan kelangsungan hidup bayi. Temuan ini sesuai dengan hasil penelitian Maisni ${ }^{13}$ dan Becher dkk, ${ }^{15}$ yang menemukan bahwa risiko untuk mengalami kematian bayi laki-laki dan bayi perempuan adalah sama. Sebaliknya, Kabir dkk ${ }^{16}$ di Bangladesh menemukan bahwa risiko kematian bayi perempuan $(27 \%)$ lebih rendah daripada bayi laki-laki, hal ini disebabkan oleh faktor biologis yang lebih berisiko pada bayi laki-laki .

Faktor berat badan lahir merupakan faktor risiko penting kelangsungan hidup bayi. Namun, pengaruh berat badan lahir terhadap kelangsungan hidup bayi di perkotaan Indonesia tergantung pada penolong persalinan. Di pedesaan, berat badan lahir berhubungan secara bermakna terhadap kelangsungan hidup bayi. Sedangkan bayi yang tidak ditimbang berisiko 1,506 kali lebih besar untuk meningal daripada bayi dengan berat badan lahir normal. Hal ini mengindikasikan kemungkinan persalinan tenaga kesehatan di fasilitas kesehatan yang rendah sehingga bayi kemungkinan tidak mendapat perawatan yang tepat. Risiko kematian bayi BBLR yang tinggi mengindikasikan bahwa berat badan saat lahir merupakan faktor penentu kelangsungan hidup bayi. ${ }^{17}$ Kemungkinan hal tersebut disebabkan oleh komplikasi gejala sisa.

Penelitian ini menemukan jarak kelahiran tidak berhubungan secara bermakna dengan kelangsungan hidup bayi di perkotaan dan pedesaan. Padahal, menurut Siagian ${ }^{18}$ persalinan yang berturut-turut dalam jangka waktu relatif singkat akan mengakibatkan uterus menjadi fibrotik yang menyebabkan kontraksi uterus yang kurang baik. Dibutuhkan waktu 2-4 tahun untuk memulihkan kondisi ibu ter- sebut. Jarak kehamilan yang terlalu dekat juga mengakibatkan ibu harus membagi perhatiannya kepada dua anak pada saat yang bersamaan. Oleh sebab itu, anak-anak yang lahir berdekatan diperkirakan berisiko kematian yang tinggi. Royston dan Armstrong ${ }^{19}$ mengemukakan dua faktor yang menyebabkan interval antara dua kelahiran pendek, yaitu waktu pemberian ASI dan cukupan pelayanan kontrasepsi yang rendah. Temuan yang bertentangan dengan temuan sebelumnya kemungkinan berhubungan dangan karakteristik ini yang belum dapat dijelaskan,

Berdasarkan urutan kelahiran, terlihat bahwa bayi anak ke-5 atau berisiko lebih tinggi untuk mengalami kematian, sebagai akibat kurang mendapat perhatian, juga karena umur yang tua. Hubungan kematian anak dan urutan kelahiran sebagian dapat diterangkan melalui berat badan lahir rendah. Proporsi BBLR meningkat mulai pada kelahiran ke-4. ${ }^{6}$ Di daerah yang memandang kematian anak sebagai peristiwa biasa, umumnya terlihat keluarga besar karena mereka tidak menduga anaknya dapat hidup. ${ }^{19}$

Di pedesaan, kelangsungan hidup bayi yang diberi ASI setelah 1 jam kelahiran lebih tinggi daripada bayi yang segera diberi ASI. Hal ini kemungkinan berhubungan dengan persalinan tidak ditolong oleh tenaga kesehatan sehingga bayi tidak mendapatkan perawatan yang memadai. Di pedesaan, bayi yang tidak ditimbang mengindikasikan persalinan bukan tenaga kesehatan. Kesulitan menyusui akan dialami oleh bayi dengan kelainan seperti kejang, sakit berat, memerlukan observasi atau terapi khusus, berat badan lahir sangat rendah, cacat bawaan dan kelainan metabolik. ${ }^{20}$ Alpu dan Fidan ${ }^{21}$ menyatakan ASI memberikan efek yang positif menghindari kematian pada bayi. Hasil ini menunjukkan bahwa pemberian ASI pada bayi harus diberikan sesegera mungkin, karena daya isap bayi pada saat lahir paling kuat, gerakan untuk mengisap pada bayi baru lahir akan mencapai puncaknya pada waktu berusia 20-30 menit.

\section{Kesimpulan}

1. Tidak ada perbedaan risiko kematian bayi di pedesaan dengan di perkotaan. Probabilitas kelangsungan hidup bayi menurun tajam pada bulan pertama (neonatal). Di perkotaan penurunan tersebut lebih landai daripada di pedesaan.

2. Faktor-faktor yang berhubungan dengan kelangsungan hidup bayi di perkotaan adalah waktu pemberian ASI, interaksi antara penolong persalinan dengan berat badan lahir setelah dikontrol faktor frekuensi kunjungan pelayanan antenatal, tempat persalinan, dan nomor urut lahir.

3. Faktor-faktor yang berhubungan dengan kelangsungan hidup bayi di pedesaan adalah frekuensi pelayanan antenatal, berat badan lahir, nomor urut lahir, tempat persalinan, interaksi penolong persalinan dengan waktu pemberian ASI setelah dikontrol faktor jarak kelahiran dan jenis kelamin. 
4. Faktor dominan yang berhubungan dengan kelangsungan hidup bayi adalah diberikan / tidaknya ASI pertama kali setelah lahir.

\section{Saran}

Untuk masyarakat pedesaaan:

1. Cakupan pemeriksaan antenatal dengan frekuensi dan kualitas yang sesuai dengan standar minimal perlu ditingkatkan, karena masih merupakan sarana paling penting untuk penyuluhan, skrining faktor resiko pengobatan penyakit berikut komplikasinya.

2. Banyak bayi yang tidak ditimbang mengindikasikan persalinan di rumah yang masih tinggi sehingga memerlukan upaya untuk meningkatkan jumlah, kualitas, pemerataan, tenaga kesehatan dan akses masyarakat. Penempatan bidan di desa perlu terus ditingkatkan guna meningkatkan jangkauan persalinan tenaga kesehatan dan meningkatkan kesadaran masyarakat tentang pentingnya persalinan yang bersih dan aman.

3. Memperluas upaya kemitraan berbagai komponen yang berhubungan dengan kematian ibu. Para ibu, masyarakat dan dukun bayi serta bidan dan dengan penentu kebijakan di tiap daerah untuk bersama-sama melakukan program peningkatan kelangsungan hidup bayi.

4. Memasyarakatkan penggunaan kontrasepsi untuk memperpanjang jarak kelahiran dan menunda kehamilan, menunda usia perkawinan yang muda, dan megurangi jumlah anak.

5. Meningkatkan kesadaran ibu untuk memberikan ASI kepada bayi segera setelah lahir dan kemampuan tenaga kesehatan untuk membantu ibu memberi ASI segera setelah bayi lahir.

Untuk masyarakat perkotaan;

1. Meningkatkan kemampuan dan ketrampilan tenaga kesehatan baik di fasilitas kesehatan maupun di masyarakat untuk dapat melakukan tata laksana yang tepat pada bayi baru lahir terutama bayi BBLR.

2. Meningkatkan kesadaran ibu untuk memberikan ASI kepada bayi segera setelah lahir. Hal ini dapat dicapai dengan cara membekali ibu hamil dengan pengetahuan tentang perawatan payudara dan bersiap memberikan ASI pada bayi. Fasilitas pelayanan kesehatan perlu menerapkan upaya rawat gabung ibu dan bayi.

3. Perlu dilakukan penelitian lebih lanjut dengan menggunakan rancangan penelitian kohord prospektif sehingga faktor risiko kelangsungan hidup bayi dapat dideteksi lebih baik.

\section{Daftar Pustaka}

1. Departemen Kesehatan Republik Indonesia. Profil kesehatan Indonesia 2002. Pusat Data dan Informasi. Jakarta: Departeman Kesehatan RI; 2004.

2. Mosley, W. H, Lincoln C.Chen. Child survival, strategies for research: population and development review. Cambridge University Press; 1984.

3. Nelson. Ilmu kesehatan anak. Edisi 12, Bagian 1. Jakarta: EGC; 1985.
4. Irianto, Joko, Soemantri S, Afifah T. Tren angka kematian bayi dan angka kematian anak balita di Indonesia. Bulletin Penelitian Kesehatan 2003; 31(4): 197-210.

5. Departemen Kesehatan RI. Pedoman pemantauan wilayah setempat kesehatan ibu dan anak (PWS-KIA). Direktorat Jenderal Bina Kesehatan Masyarakat. Direktorat Kesehatan Keluarga. Jakarta. 2003.

6. Utomo, Budi. Kelangsungan hidup anak di Indonesia: pengertian, masalah, program, dan bahasan metodologis. Jakarta : Pusat Penelitian Kesehatan Lembaga Penelitian Universitas Indonesia; 1988.

7. Zahid, Mustafa, G. Impact of maternal education and health-related behaviours on infant and child survival in Pakistan. University of Western Ontario London. Canada. 2000. Diakses 19 Februari 2005. http://www.canpopsoc.org.

8. Asefa, Makonnen, Robert Drewett, Fasil Tessema. A birth kohort study in south-west Ethiopia to identify faktors associated with infant mortality that are amenable for intervention. The Ethiopian Journal of Health Development 14 (2): 2000;161-168. Diakses 3 Mei 2005, http://www.cih.vib/journal.

9. Wibowo, Adik. Faktor-faktor yang berhubungan dengan pemanfaatan pelayanan antenatal dan kaitannya dengan berat badan lahir rendah. [Disertasi].Jakarta: Fakultas Kesehatan Masyarakat Universitas Indonesia; 1992.

10. Kurniawati. Identifikasi faktor risiko yang erat hubungannya dengan kejadian tetanus neonatorium di Kabupaten Serang Tahun 1994-1995. [Tesis]. Jakarta: Fakultas Kesehatan Masyarakat Universitas Indonesia; 1996.

11. Harto, Edi Puji. Kematian bayi di Kabupaten Purworejo kajian dari pemanfaatan pelayanan kesehatan dan kondisi Sanitasi Lingkungan. [Tesis]. Yogyakarta: Universitas Gadjah Mada; 2000.

12. Departemen Kesehatan RI. Indikator Indonesia sehat 2010 dan pedoman penetapan indikator propinsi sehat dan kabupaten/kota sehat. SK Menkes No. 1202/ Menkes/ VIII/ 2003. Jakarta; 2003.

13. Maisni, Childa. Gambaran lama ketahanan hidup bayi dan faktor-faktor yang berhubungan. [Tesis]. Jakarta: Fakultas Kesehatan Masyarakat Universitas Indonesia; 2000.

14. Taffa, Negussie, Francis Obare. Pregnancy and child health outcomes among adolescents in Ethiopia. The Ethipia Journal Health Development, 18 (2), 2004; 90-5

15. Becher, Heiko, Muller O, Albert. J, Adjima G, Gisela KW. Bocar. Risk faktors of infant and child mortality in rural burkina faso. Bulletin of the World Health Organization, April 2004; 82 (4); 265-273. Diakses 19 Februari 2005 http://www.who.int.

16. Kabir, Ahmad, M.S. Islam, M.S Ahmad, M.A. Khalique B. Factors influencing infant and child mortality in Bangladesh. The Sciences 1 (5) SeptemberOktober 2001; 292-295. Diakses 12 Maret 2005, http://www.ansinet.org.

17. Departemen Kesehatan RI, Pedoman pengukuran lingkar dada (LIDA) pada bayi baru lahir, sebagai indikator deteksi dini bayi berat lahir rendah. Jakarta; 1997.

18. Siagian, P.E.L. Perdarahan postpartum di RS Hasan Sadikin Bandung selama periode 1970-1974. Bagian Ostetrik dan Ginekologi. Bandung: FK Unpad RSHS; 1997.

19. Royston, Erica dan Sue Armstrong. Pencegahan kematian ibu hamil. WHO; 1989.

20. Wiknjosastro, Hanifa. Ilmu kebidanan. Jakarta: Yayasan Bina Pustaka Sarwono Prawirohardjo; 2002.

21. Alpu, Ozlem and Hatice Fidan. Sequantial probit model for infant mortality modeling in Turkey. Journal of Applied Sciences 4 (4), 2004; 590-595. Diakses 3 Mei 2005, http://www.ansinet.org. 